\title{
Correlation between Serum Magnesium and Parathyroid Hormone in Hemodialysis Patients
}

Amir Mohammed El okely, Ahmed Ghareeb Menshawy, Mohamoud Hosny Zahran

Department of internal medicine, Faculty of Medicine, Zagazig University, Egypt.

Correspondence to: Ahmed Ghareeb Menshawy, Department of internal medicine, Faculty of Medicine, Zagazig University, Egypt.

Email:

ahmedhegab091@gmail.com

Received: 2 March, 2020

Accepted: 25 July, 2020

\begin{abstract}
:
Background: It is considerable that chronic kidney disease-mineral bone disorder (CKD-MBD) is a vital issue in chronic kidney disease patients. Parathyroid hormone (PTH) is a fundamental factor in the pathogenesis of this disorder in dialysis patients. It is believed that plasma magnesium $\left(\mathrm{Mg}^{2+}\right)$ has an essential role in the regulation of PTH secretion in a manner which is slightly similar to calcium. Objectives: Illustrates the relationship between serum magnesium and serum parathyroid hormone in hemodialysis patients. Patients and Methods: A cross-sectional study had been carried out in the Hemodialysis Unit, Zagazig University Hospitals, Faculty of medicine, Zagazig University from the period between December 2018 and May 2019. The study included (77) participants diagnosed with end stage renal disease on regular hemodialysis. Results: There is no statistically significant correlation between serum magnesium and serum parathyroid hormone. Conclusion: Our findings suggest that
\end{abstract} Our findings require further investigations with larger and multicentric studies.

Key words: Magnesium; Parathyroid Hormone; Hyperparathyroidism, Secondary; End-Stage Kidney Disease. 


\section{Introduction}

No doubt that chronic kidney disease-mineral bone disorder (CKD-MBD) is considered an important issue of chronic kidney disease [1]. Parathyroid hormone $(\mathrm{PTH})$ is a fundamental factor in the pathogenesis of this disorder in dialysis patients. The balance of electrolytes including phosphorus $(\mathrm{P} 3+)$, calcium $(\mathrm{Ca} 2+)$, and magnesium $(\mathrm{Mg} 2+)$ is disturbed in such patients [2]. $\mathrm{Mg} 2+$ is broadly excreted by the kidney, so the equilibrium of $\mathrm{Mg} 2+$ is disrupted in chronic kidney disease. The homeostasis of $\mathrm{Mg} 2+$ metabolism is balanced by renal filtration and reabsorption [3]. In ancient times, studies on the mineral and bone disorder in chronic kidney disease focused on the disarray of calcium and phosphorus homeostasis [4]. Plentiful studies have elucidated that $\mathrm{Mg} 2+$ plays a crucial role in the pathophysiology of the cardiovascular system; additionally, its disorder is greatly accompanied with the increased cardiovascular morbidity and mortality. [5] Moreover, it is assumed that $\mathrm{Mg} 2+$ is involved in the regulatory process of PTH secretion . [6[

\section{Aim of the work}

Illustrates the relationship between serum magnesium and serum parathyroid hormone in hemodialysis patients.

\section{Subjects and methods}

Type of study: cross-sectional study.

Site of study: The study had been carried out in the Hemodialysis Unit, Zagazig University Hospitals, Faculty of medicine, Zagazig University from the period between December 2018 and May 2019.

Sample size: The total end stage renal disease patients on regular hemodialysis were 95 patients in six months and prevalence of hypermagnesaemia was $50 \%$, so the sample size was 77 , CI $95 \%$, power of test $80 \%$. The sample size was calculated by OpenEpi programme .

Inclusion criteria: Age group above 18 years old of both sex (males and females) who have been diagnosed with end stage renal disease with three months history of dialysis (Mean \pm SD of the years of the dialysis was $3.76 \pm 1.65$ ) on a schedule of 3 times/week, 3-4 h for each session. The magnesium concentration in the dialysate was $.50 \mathrm{mmol} / \mathrm{L}$

Exclusion criteria: Patients with septicemia or have any source of infection or malignancy, patients with history of parathyroidectomy, chronic diarrhea and patients taking magnesium containing antacids . 
Methods :

Medical History: detailed past and present medical history .

Blood pressure was measured by a mercury sphygmomanometer with the subject recumbent in bed with the arm supported and positioned at the level of the heart, pulse examination to show any abnormality and any special character, temperature and respiratory rate, general examination, local examination of cardiovascular, respiratory, gastroenterology, hepatology, and neurology systems.

\section{Laboratory investigations:}

Routine investigations in the form of serum calcium (mg/dl), serum Phosphorus (mg/dl), serum magnesium (mg/dl), serum alkaline phosphatase (U/L), serum albumin (g/dl), serum creatinine $(\mathrm{mg} / \mathrm{dl})$, serum urea $(\mathrm{mg} / \mathrm{dl})$, complete blood count (CBC).They were measured using standard kits.

The serum calcium levels of blood were corrected with regard to the albumin levels.

The efficacy of HD was assessed by calculating the urea reduction rate (URR). (Mean \pm SD of the URR was 60.6 \pm 7.78. Special investigation in the form of serum intact PTH $(\mathrm{pg} / \mathrm{ml})$. It was measured by the electrochemiluminescence immunoassay
(ECLIA) depending on Elecsys and cobas with immunoassay analyze.

Consent: written informed consent was obtained from all participants and the study was approved by the research ethical committee of faculty of medicine, Zagazig University with a number of \#4972-6-11-2018. The work has been carried out in accordance with the code of ethics of the world medical association (Declaration of Helsinki) for studies involving humans.

Statistical analysis

Data analysis was performed using the software SPSS (Statistical Package for the Social Sciences) version 20. Quantitative variables were described using their means and standard deviations. Categorical variables were described using their absolute frequencies and were compared using Chi square test.

Kolmogor-ov-Smirnov (distribution-type) and Levene (homogeneity of variances) tests were used to verify assumptions for use in parametric tests. The level statistical significance was set at $5 \%(\mathrm{P}<0.05)$. Highly significant difference was present if $\mathrm{p} \leq .001$. 


\section{Result:}

In this study, 77 patients (41 females and 36 males, representing $53.2 \%$ and $46.8 \%$ respectively) demonstrated that: the mean $\pm \mathrm{SD}$ of the measured parameters was $2.18 \pm 0.42$ $\mathrm{mg} / \mathrm{dl}$ for serum magnesium, $555.09 \pm 551.8$ $\mathrm{pg} / \mathrm{ml}$ (range 10 - 2907) for serum PTH, $4.87 \pm$ $1.17 \mathrm{mg} / \mathrm{dl}$ for serum phosphorus and the mean $\pm \mathrm{SD}$ of the years of the dialysis was $3.76 \pm$ 1.65. (table 1 and fig.1).

There is no statistically significant correlation between serum magnesium and serum parathyroid hormone. (Table 2). Additionally, Table (1) laboratory investigations of the studied patients

\begin{tabular}{|c|c|c|}
\hline $\begin{array}{l}\text { Laboratoty } \\
\text { investigations }\end{array}$ & Mean \pm SD & Range \\
\hline Hemoglobin (g/dl) & $9.97 \pm 1.75$ & $7-16$ \\
\hline WBCs $\left(* 10^{3} / \mathrm{mm}^{3}\right)$ & $6.06 \pm 1.79$ & $3-14$ \\
\hline Platelet count $\left(* 10^{3} / \mathrm{mm}^{3}\right)$ & $206.18 \pm 66.43$ & $97-451$ \\
\hline Serum creatinine & $9.9 \pm 2.2$ & $5-18$ \\
\hline Serum urea & $63.39 \pm 14.05$ & $35-99$ \\
\hline Serum albumin & $3.68 \pm 0.52$ & $2-5$ \\
\hline Serum calcium (mg/dl) & $8.08 \pm 0.81$ & $6-11$ \\
\hline $\begin{array}{l}\text { Corrected calcium } \\
(\mathrm{mg} / \mathrm{dl})\end{array}$ & $8.32 \pm 0.82$ & $7-11$ \\
\hline $\begin{array}{l}\text { Serum phosphorus } \\
(\mathrm{mg} / \mathrm{dl})\end{array}$ & $4.87 \pm 1.17$ & $3-8$ \\
\hline Serum magnesium & $2.18 \pm 0.42$ & $2-4$ \\
\hline \multirow[t]{2}{*}{ Urea reduction rate } & $60.6 \pm 7.78$ & $50-76$ \\
\hline & Mean \pm SD & Median (range) \\
\hline $\begin{array}{l}\text { Serum parathyroid } \\
\text { hormone }\end{array}$ & $555.09 \pm 551.8$ & $388(10-2907)$ \\
\hline $\begin{array}{l}\text { Serum alkaline } \\
\text { phosphatase (U/L) }\end{array}$ & $243.95 \pm 162.55$ & $200(36-822)$ \\
\hline
\end{tabular}

there is no statistically significant correlation between serum magnesium and both serum urea and creatinine. Also, there is no statistically significant correlation between it and serum alkaline phosphatase. (Table 3).

There is no statistically significant correlation between serum magnesium and both age, hemoglobin level and white blood cells. Moreover, there is no statistically significant correlation between it and platelet count. (Table 4).
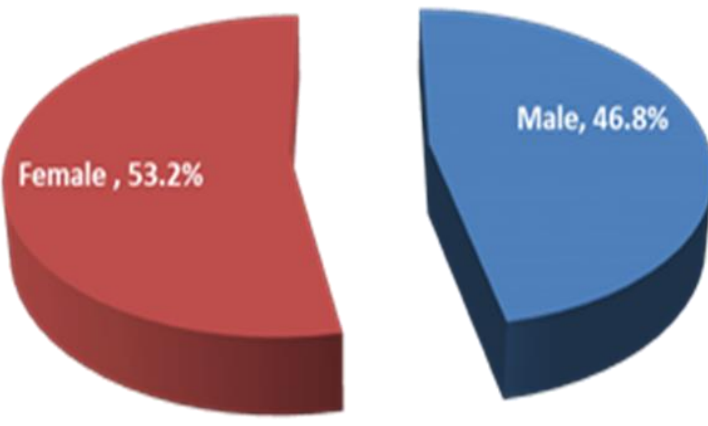

Figure (1) Pie chart showing distribution of the studied patients according to gender: 
Table (2): Correlation between serum magnesium and serum parathyroid hormone of the studied patients:

\begin{tabular}{llc}
\hline \multirow{2}{*}{ Variables } & \multicolumn{2}{c}{ Serum magnesium (mg/dl) } \\
\hline & $\mathrm{r}$ & $\mathrm{p}$ \\
\cline { 2 - 3 } Serum parathyroid hormone (mg/dl) & -0.011 & 0.926 \\
\hline & & \\
$\infty$ Spearman correlation coefficient & &
\end{tabular}

Table (3): Correlation between serum magnesium and both age and both Serum alkaline phosphatase and kidney function test of the studied patients:

\begin{tabular}{lcc}
\hline Variables & \multicolumn{2}{c}{ Serum magnesium $(\mathrm{mg} / \mathrm{dl})$} \\
\hline & $\mathrm{r}$ & $\mathrm{p}$ \\
Serum urea $(\mathrm{mg} / \mathrm{dl})$ & 0.175 & 0.128 \\
Serum creatinine $(\mathrm{mg} / \mathrm{dl})$ & 0.135 & 0.243 \\
Serum alkaline phosphatase (U/L) & $-0.027^{\infty}$ & 0.815 \\
\hline
\end{tabular}

r Pearson correlation coefficient ${ }^{\infty}$ Spearman correlation coefficient

Table (4): Correlation between serum magnesium and both age and complete blood count findings of the studied patients

\begin{tabular}{lll}
\hline Variables & \multicolumn{2}{l}{ Serum magnesium } \\
\hline & $\mathbf{r}$ & $\mathbf{P}$ \\
\cline { 2 - 3 } & 0.147 & 0.12 \\
Age & 0.114 & 0.324 \\
Hemoglobin $(\mathrm{g} / \mathrm{dl})$ & 0.071 & 0.538 \\
White blood cells $\left(* 10^{3} / \mathrm{mm}^{3}\right)$ & -0.179 & 0.12 \\
Platelet count $\left(* 10^{3} / \mathrm{mm}^{3}\right)$ & & \\
\hline
\end{tabular}

r Pearson correlation coefficient 



\section{Discussion}

Chronic kidney disease-mineral bone disorder is a considerable issue in the causality of the higher incidence of cardiovascular morbidity and mortality in end-stage renal disease. . [7]. In comparison to the obvious attention in the disruption of calcium and phosphate metabolism in the pathogenesis of the vascular/valvular calcification, magnesium metabolism is considered far away and the clinical problems associated with it are still not well understood by nephrologists. . [8]

The fact shows that different complications of secondary hyperparathyroidism are poorly reversible if they passed untreated, so there is a need for the early management of its causes. [9]

Independent of the calcium and phosphorus, which are essential in the regulation of parathyroid gland function; it is thought that magnesium is capable of modulating parathyroid hormone secretion in a way as calcium does. . [10]

In this study, 77 patients revealed that serum magnesium has no statistically significant correlation with serum alkaline phosphatase $(\mathrm{r}=$ 0.837, $\mathrm{p}=0.815)$. In agreement with Nasri and Baradaran ,[11] who stated that there was no significant correlation between serum magnesium levels and alkaline phosphatase in their cross-sectional study on 41 patients on maintenance hemodialysis. This is in contrast to Fang et al., [12], who found that there is an inverse relationship between alkaline phosphatase and serum magnesium in their study on their cross-sectional study that was conducted on 111 patients on maintenance hemodialysis ( $\mathrm{r}$ $=-0.198, \mathrm{p}=0.037)$.

In this study, there is no statistically significant correlation between serum magnesium and hemoglobin level $(\mathrm{p}=0.324, \mathrm{r}=0.114)$. This is in contrast with Fang et al., [12], who found that serum magnesium levels were positively correlated with hemoglobin level. $(\mathrm{p}=0.017, \mathrm{r}=$ $0.225)$

In addition, there is a non-statistically significant correlation between serum magnesium levels and platelet count $(\mathrm{p}=0.12, \mathrm{r}=-0.179)$. In contrast to Fang et al., [12], who found that serum magnesium levels were positively correlated with platelets count $(\mathrm{p}=0.011, \mathrm{r}=$ $0.240)$

In this study, there is a non-statistically significant correlation between serum magnesium and both serum urea and creatinine ( $\mathrm{p}=0.128$ and $0.243, \mathrm{r}=0.175$ and 0.135 respectively). This is in contrast with Fang et al., [12], who found that serum magnesium levels were positively correlated with both serum urea and creatinine $(\mathrm{p}=0.000, \mathrm{r}=0.389$ for both $)$ 
In this study, there is no statistically significant correlation between serum magnesium and serum parathyroid hormone $(\mathrm{p}=0.926, \mathrm{r}=-$ 0.011). This is in agreement with Nasri and Baradaran [11], who involved 41 patients with ESRD on regular maintenance HD treatment and found a non-statistically significant correlation between the serum magnesium levels and parathyroid hormone levels $(\mathrm{p}=0.079, \mathrm{r}=-$ $0.30)$.

Also, Fang et al., [12], stated that there were no statistically significant correlations between serum magnesium and parathyroid hormone levels in hemodialysis patients $(\mathrm{r}=-0.143, \mathrm{p}=$ 0.134). In contrast, Ohya et al., [13] found that the serum magnesium level was significantly higher in patients with low parathyroid hormone levels and they also concluded that serum parathyroid hormone levels had a significant negative correlation with the serum magnesium levels in their study on 1231 ESRD patients in Japan ( $\mathrm{p}<$ 0.01). Also, Gohda et al., [14] conducted a study on 86 HD patients not treated with vitamin $\mathrm{D}$ and found that their serum parathyroid hormone levels had a significant negative correlation with the serum magnesium levels $(\mathrm{p}<0.001, \mathrm{r}=-0.28)$.

On the other hand, Fooladgar et al., [15] conducted a study on 52 HD patients and found a significantly positive correlation of serum magnesium and parathyroid hormone levels $(\mathrm{r}=$ $0.28, \mathrm{P}=0.04)$

\section{Conclusion}

A non-statistically significant correlation was found between serum Mg and serum PTH levels. Our findings suggest that factors other than serum $\mathrm{Mg}$ may be more important in the regulation of PTH secretion.

Limitations of the study: Proportion of hemodialysis patients is relatively small. We suggest larger multicentric investigations on this aspect of hemodialysis individuals.

\section{References}

.1 Moe SM, Drüeke T, Lameire N, Eknoyan G. Chronic kidney disease-mineral-bone disorder: a new paradigm. Adv Chronic Kidney Dis. 2007 Jan 1;14(1):3-12.

.2 Ahmadi F, Mohebbi Z, Mahdavi-Mazdeh M, LessanPezeshki M. Relationship of circulating levels of $25(\mathrm{OH})$ vitamin D with parathyroid hormone in Iranian patients with chronic kidney disease not yet on dialysis; what is the best threshold for 25 (OH) vitamin D. J Parathyr Dis. 2017 Sep;5:32-7.

.3 Li W, Zhang S. Risk Factors of Parathyroid Dysfunction in Elderly Patients with Chronic Kidney Disease Undergoing Hemodialysis. Adv Clin Exp Med: official organ Wroclaw Medical University. 2015;24(6):1007-12.

.4 West SL, Swan VJ, Jamal SA. Effects of calcium on cardiovascular events in patients with kidney disease and in a healthy population. Clin J Am Soc Nephrol. 2010 Jan 1;5(Supplement 1):S41-7.

.5 Kolte D, Vijayaraghavan K, Khera S, Sica DA, Frishman WH. Role of magnesium in cardiovascular diseases. Cardiol Rev. 2014 Jul 1;22(4):182-92. 
.6 Dousdampanis P, Trigka K, Fourtounas C. Hypomagnesemia, chronic kidney disease and cardiovascular mortality: pronounced association but unproven causation. Hemodial Int. 2014 Oct;18(4):730-9.

.7 Yokoyama K, Taniguchi M, Fukagawa M. A Japanese approach for CKD-MBD. Kidney Int. Suppl. 2013 Dec 2;3(5):451-6.

.8 Spiegel DM. Magnesium in chronic kidney disease: unanswered questions. Blood purification. 2011;31(13):172-6.

9 Hörl WH. Secondary hyperparathyroidism: present and future therapeutic implications.Nephrol Dial Transplant. 2002 May 1;17(5):732-3.

.10 Cho MS, Lee KS, Lee YK, Ma SK, Ko JH, Kim SW, et al. Relationship between the serum parathyroid hormone and magnesium levels in continuous ambulatory peritoneal dialysis (CAPD) patients using low-magnesium peritoneal dialysate. KOREAN J INTERN MED. 2002 Jun;17(2):114.

.11 Nasri H, Baradaran A. Correlation of serum magnesium with dyslipidemia in maintenance hemodialysis patients. Acta Medica (Hradec Kralove). 2004;47(4):263-5.

.12 Fang L, Tang B, Hou D, Meng M, Xiong M, Yang J. Effect of parathyroid hormone on serum magnesium levels: the neglected relationship in hemodialysis patients with secondary hyperparathyroidism. Renal failure. 2016 Jan 2;38(1):50-6.

.13 Ohya M, Negi S, Sakaguchi T, Koiwa F, Ando R, Komatsu Y, et al. Significance of serum magnesium as an independent correlative factor on the parathyroid hormone level in uremic patients. J. Clin. Endocrinol. Metab. 2014 Oct 1;99(10):3873-8.

.14 Gohda T, Shou I, Fukui M, Funabiki K, Horikoshi S, Shirato I, et al. Parathyroid hormone gene polymorphism and secondary hyperparathyroidism in hemodialysis patients. Am J Kidney Dis. 2002 Jun 1;39(6):1255-60.

15. Fooladgar M, Malekpour Tehrani A, AsgariSavadjani S, Mardani S. Serum magnesium in association with parathyroid hormone levels in routine hemodialysis patients. J parathyr dis. 2017; 6(1).

To cite this article: Amir Mohammed El okely, Ahmed Ghareeb Menshawy, Mohamoud Hosny Zahran. Correlation between Serum Magnesium and Parathyroid Hormone in Hemodialysis Patients. BMFJ 2020; 37 (Internal medicine and Hepatology): 91-98. DOI: 10.21608/bmfj.2020.25062.1224 